\title{
EMPLOYEE ENGAGEMENT AND IMPROVEMENT AS IMPORTANT PRINCIPLES OF TQM IN PUBLIC HEALTH INSTITUTES
}

\author{
Ana-Marija Vrtodušić Hrgović \\ PhD, Associate Professor, University of Rijeka, Faculty of Tourism and Hospitality Management, \\ Primorska 42, P.O.B. 97, 51410 Opatija, Croatia; e-mail: anamariv@fthm.hr \\ Kristina Črnjar \\ PhD, Associate Professor, University of Rijeka, Faculty of Tourism and Hospitality Management, \\ Primorska 42, P.O.B. 97, 51410 Opatija, Croatia; e-mail: kcrnjar@fthm.hr

\section{Ivana Škarica} \\ Mag. oec., PhD Student, University of Rijeka, Faculty of Tourism and Hospitality Management, \\ Primorska 42, P.O.B. 97, 51410 Opatija, Croatia; e-mail: ivanaskarica969@gmail.com
}

\begin{abstract}
Quality assurance in public health presents one of the key factors in the quality of health service. Accordingly, there is increasing awareness of the need to integrate quality systems and their principles into the healthcare system. Their role is important in the context of quality assurance in accordance with patient requirements as well as in the process of improving the quality of health care service. They are essential for the successful implementation of a quality management system and refer to customer focus, leadership, engagement of people, process approach, improvement, evidence-based decision making, and relationship management. This paper presents the results of a study among Croatian Institutes of Public Health with regard to the level of implementation of quality principles related to employee engagement, improvement and internal customer focus. Analysis focused on the relationship between focus on internal customer (employees) and improvements as well as the employee engagement and improvement respectively. Results show there is a strong positive relationship between employee engagement and improvements, while between internal customer focus and improvement the relationship has not been verified. In the context of standardization of quality of public health services, the paper aims to expand theoretical knowledge about TQM principles, with the emphasis on the employee engagement, internal customer focus (employees) and process improvement. The results can serve as a basis for improving the existing practice of quality management system implementation in the public health sector, with emphasis on employees.
\end{abstract}

Key words: Total Quality Management, employee engagement, internal customerfocus, improvement, public health institutes 


\section{INTRODUCTION}

In the past, many healthcare institutions were characterised by the lack of an integrative approach to quality; attempts to improve quality were fragmented and inconsistent and all the efforts in this field were based on individual quality projects. The management of employees was given low priority in healthcare institutions. Often, employee management relating to TQM was mostly instrumental, with a strong focus on standardizing professional behaviour, selection procedures and training programmes, putting little or no emphasis on development, and employee satisfaction and engagement (Schalk, Van Dijk, 2005). Only in the last decade has a more systematic and structured approach to quality been adopted, the main goal being the harmonization of existing quality programmes and overall optimization of the healthcare system in order to promote, among other things, the principles and values of Total Quality Management (TQM). In relation to that this paper is focused on the implementation of the TQM principles in the Institutes of Public Health in Croatia in particular on the employee engagement, quality improvements and internal customer focus.

\section{LITERATURE REVIEW}

To achieve sustainable success, healthcare institutions will be seeking ways to reach maximum efficiency in the performance of all processes by optimizing procedures with minimum effort of time and costs. In order to reach this goal, they will have to rely on their employees to execute tasks to the best of their ability based on their knowledge and competences (Werner, Weckenmann, 2012: 1534). Employees' knowledge, competences, engagement and commitment will give a company a critical competitive advantage.

Quality can be defined as a satisfied external customer, the road to which is paved by satisfied internal customers (Varey, 1995:46). The cooperation and commitment of all employees, together with well-developed customer-supplier relationships and a quality culture, will be the source of differentiation for institutions striving to achieve customer satisfaction. Individual people's involvement will be a key component in implementing Total Quality Management in the institution.

According to Oakland, TQM is "an approach to improving the competitiveness, effectiveness and flexibility of a whole organization. It is essentially a way of planning, organizing and understanding each activity and depends on each individual at each level." (Oakland, 2003:30). The ISO 9000 standard defines it as a part of the management system with regard to quality (ISO 9000:2015: 17)

According to the same standard, a quality management system is based on seven guiding principles that represent a set of fundamental beliefs, norms, rules and values that are accepted (Quality Management Principles, 2015) and refer to customer focus, leadership, engagement of people, process approach, improvement, evidence-based decision making and relationship management.

Employee engagement is a concept trying to understand and therefore describe the relationship between the organization and its employees by using quantitative and qualitative elements. An "engaged employee" is defined as one who is fully absorbed by and enthusiastic about their work 
and so takes positive action to further the organization's reputation and interests. An engaged employee has a positive attitude towards the organization and its values (Paul, 2017).

There is a lack of universal definition of "employee engagement" presented by researchers and organizations. William Kahn provided the first formal definition of personnel engagement as "the harnessing of organisation members' selves to their work roles; in engagement, people employ and express themselves physically, cognitively, and emotionally during role performances" (Kahn, 1990).

In the effort to introduce an integrative quality management approach in the institution such as Total Quality Management employees will be main driver of the implementation process. This approach will require dealing with a whole set of activities focusing on management of human resources such as employees' satisfaction, commitment (especially top management), empowerment and training. M. Urbaniak argues that organisations that put a particular emphasis on the process of personnel management, especially on raising personnel qualification by investing in its development, achieve higher employee engagement in improvement of processes, efficiently affecting their attitude regarding identification of problems and problem solving as well as reporting improvement initiatives (Brajer-Marczak 2014, p. 97).

In addition to quality measurements and benchmarking, process management, product design, supplier quality management and customer involvement and satisfaction need to be addressed. Employee satisfaction and the quality of process control is closely and directly related to employee commitment. To a lesser degree this also applies to measurement/registration and guidelines and protocols which will work only when employees are committed. Employees must be focused on the company's philosophy of commitment to never-ending improvement, be informed of the company's goals and be made to feel part of the team (Schalk, Van Dijk, 2005:1719).

In the last years' employee engagement is strongly emblemized as a strategic business objective that can secure productivity, improvement in quality of work, motivation and consequently long-term retention of employees. By studding companies with over fifty-hundred employees' researchers found that $71 \%$ of managers do see employee engagement as one of the key factor in overall company success. At the same time only $33 \%$ of employees, as shown in the Gallup research, perceive themselves as engaged at work. There are a whole set of factors influencing this kind of disengagement from the employees' side like lack of recognition in the company for the effort and work rendered, poor company communication and poor understanding of the company vision and mission (Brook, 2017).

The engagement of people emphasizes the importance of involving all people at all levels and respecting them as individuals in order to manage an organization effectively and efficiently (Quality Management principles, 2015). The importance of employee engagement is also emphasized in ISO 9001, as part of the requirement related to Resource Management, including Human Resource Management. In relation to managing human resources, focus is given to their expertise, training, awareness and communication. With regard to human resources, Clause 7.1.2 states that the organization shall determine and provide the persons necessary for the effective implementation of its quality management system and for the operation and control of its processes (ISO 9001:2015:6). 
Clause 7.1.6 underlines the importance of employee knowledge, stating that the organization shall determine the knowledge necessary for the operation of its processes and to achieve conformity of products and services. (ISO 9001:2015: 7) In addition to knowledge, competencies are one of the most important resources. To assure the competence of employees, the standard requires that an organization shall determine the necessary competence of persons doing work under its control that affects the performance and effectiveness of the quality management system and ensure that these persons are competent on the basis of appropriate education, training or experience (ISO 9001:2015: 8).

In order to enhance employee engagement, the collaboration and involvement of all people at all levels in the organization is important. To this end, regular education, team work and internal communication have to be fostered. Team work enables the exchange of ideas and experiences as well as providing an opportunity for employees to work together on common goals. Taking into account the fact that most of the processes involve a considerable number of employees, necessary improvements often have to be based on team learning. (Džakula et al., 2014:95). Kanji points out that the standard itself is of no importance and does not guarantee quality if there is no employee engagement and involvement (Kanji, 2002:48). Engagement of people refers to their involvement but also to the responsibility of finding opportunities for improvement on the individual as well as the team level.

"Improvement is essential for an organization to maintain current levels of performance, to react to changes in its internal and external conditions and to create new opportunities "(Quality Management Principles, 2015:10). The core of continuous improvement can best be illustrated by Deming's PDCA cycle which shows that improvement is a never-ending process that needs to be implemented daily, in all areas of business operations. "The PDCA cycle is more than just a tool; it is a concept of continuous improvement processes embedded in an organization's culture" (Soković, Pavletić, Kern Pipan, 2010:478). Kanji (2002) points out that a quality management system is not a short-term solution or a project that ends when the objective has been achieved but rather it is an organization management process that acknowledges the fact that the competition is also continuously making improvements and that customers expect any organization in the market to continuously make improvements in all segments of its business operations. Ultimately, the basis of customer satisfaction is grounded in the continuous improvement of customer-focused processes and activities (Kanji, 2002: 77). In this segment, adequate measurement - measuring progress in achieving the set goals, identifying opportunities for improvement, measuring the organization's performance against various internal and external standards, etc. - is pivotal in providing data to drive further improvement in the future.

Organizations currently compete in terms of having the capacity to improve their processes continuously. This capacity will be influenced by many factors undoubtedly employee engagement and focus on employees as internal customers are one of them (Pekar, 1995). Instruction in creating employee engagement can be found among TQM assumptions which mentioned that employees have to perceive the working environment as one that is based on cooperation, trust and openness, that they are involved in the continuous improvement process, have sufficient knowledge and skills associated and skills associated with continuous improvement of processes, employees are 
suggested constant training in "improvement of the ways of improvement" (Brajer-Marczak 2014, p. 94). Continues improvement of processes will be carried out by employees who will require analytical skills and conceptual thinking, understanding of organization goals and commitment to the costumers.

A number of researches did focus their research on human aspects in the process of implementing TQM. Tari and Sabater examined the relationship between quality management and human aspects (empowerment, recognition, personnel policies and effects on employees) and concluded that this relationship exists and that certified firms with a greater extent of quality management do show a higher interest in human aspects (Tari, Sabater, 2006:484). Mosadeghrad established a connection between employee empowerment and the implementation process of TQM, because those healthcare organizations that put more emphasis on employee empowerment are more successful in the implementation process. He argues that teamwork and participative culture contribute to employee empowerment and involvement in quality improvement activities. (Mosadeghrad, 2015:552, 553). Few studies emphasise the importance of training and education for successful TQM implementation and job involvement (Mosadeghrad, 2015: Karia, Asari, 2006)

Research findings from Salaheldin and Mukhalati (2009:1) have shown that there is a common understanding between managers in healthcare organizations about the significance of top management support, employee training and involvement in TQM implementation. Arsić et al. (2015) found that employees employed in companies with implemented quality systems are, in general, satisfied with their working conditions and committed to the organization.

\section{RESEARCH METHODOLOGY}

Public Health Institutes represent the "backbone "of public health in Croatia and therefore are represented in all Croatian counties.

The Croatian network of public health institutes consists of 21 county Institutes. Within the wide range of activities being performed within these institutes, mandatory is accreditation according to the standard ISO/IEC 17025 for activities such as safety testing for food, water, air, general use items, micro-biological cleanliness of objects and water sampling. In addition to some of the Institutes having implemented and certified ISO 9001, the above mentioned fact is the reason why 20 out of 21 county Institutes are accredited according to ISO/IEC 17025.

One of the advantages of accreditation lies in the fact that ISO/IEC 17025 includes quality principles in accordance with the ISO 9001, considered as being the first step towards TQM (Yung, 1997). Hence, all county Public Health Institutes were able to be included in this study to examine the application of TQM principles with the focus on the relationship of employee engagement and internal customer focus with improvements.

Hence, this study hypothesises the following:

H1: There is a significant positive correlation between internal customer focus (employees) and continuous improvement. 
H2: There is a significant positive correlation between employee engagement and continuous improvement.

To analyse the level of implementation of TQM principles, the study encompassed all the Croatian Institutes of Public Health. The main focus was on the extent to which TQM activities are implemented in the public health sector. Questionnaire was based on the Kanji TQM model (2002) and was adjusted to the specifics of Institutes of Public Health. The questionnaire was pretested by two employees from the Quality Department of the Teaching Institute of public health in Rijeka and it contained 48 questions in total ( 5 questions referred to Leadership, 11 to the principle Delight the customer, 7 questions referred to Continuous improvement, 9 questions to People-based management, and 16 questions to Management by fact). The questionnaire also included 2 questions focused on the information regarding quality management systems that are implemented or are planned to be implemented. Questionnaires were sent by e-mail to Quality Managers in all Public Health Institutes since each Institute appointed one Quality Manager as a Board representative. Therefore, Quality Managers formed the sample in this research.

The questionnaire contained questions in relation to the extent of implementation of quality principles by using a Likert-type scale ( 1 - very low, 5 - very high) and referred to stated principles leadership, delight the customer (internal and external), improvement, people-based management and management by fact. The response rate was $95 \%$ (20 Institutes out of total of 21). The data were analysed using methods of descriptive and inferential statistics (with SPSS, Statistical Package for the Social Sciences) v.21).

\section{RESEARCH RESULTS}

The results of the performed descriptive analysis (mean, standard deviation) for the chosen TQM principles (employee engagement, improvement and internal customer focus) are presented in table 1.

Table 1. Descriptive statistics

\begin{tabular}{|c|c|c|c|}
\hline PRINCIPLES & $\begin{array}{c}\text { CORE CONCEPTS } \\
\text { The extent to which: }\end{array}$ & MEAN & ST. DEV. \\
\hline Employee Engagement & $\begin{array}{r}\text { Feedback is provided to employees on } \\
\text { their performance }\end{array}$ & 4.15 & 0.67 \\
\hline Employee Engagement & $\begin{array}{r}\text { Quality-related training is given to } \\
\text { employees }\end{array}$ & 4.00 & 0.73 \\
\hline Employee Engagement & $\begin{array}{c}\text { Teamwork is encouraged for employees to } \\
\text { communicate to others about their jobs }\end{array}$ & 3.95 & 0.76 \\
\hline Employee Engagement & $\begin{array}{c}\text { Means are available for all employees to } \\
\text { contribute effectively to meeting the unit's } \\
\text { quality objectives }\end{array}$ & 4.15 & 0.81 \\
\hline
\end{tabular}




\begin{tabular}{|c|c|c|c|}
\hline Employee Engagement & Action-teams are used to solve problems & 3.80 & 0.70 \\
\hline Employee Engagement & $\begin{array}{l}\text { Quality-related training is given to } \\
\text { managers }\end{array}$ & 4.11 & 0.74 \\
\hline Employee Engagement & $\begin{array}{l}\text { There are resources available for employee } \\
\text { training }\end{array}$ & 4.11 & 0.74 \\
\hline Employee Engagement & $\begin{array}{l}\text { Managers remove the barriers that } \\
\text { prevent people from improving quality }\end{array}$ & 3.95 & 0.61 \\
\hline Employee Engagement & People are proud to work for the unit & 4.00 & 0.73 \\
\hline Improvement & $\begin{array}{l}\text { Quality improvement methods are used } \\
\text { to improve all services }\end{array}$ & 4.05 & 0.83 \\
\hline Improvement & $\begin{array}{l}\text { Processes are designed to prevent } \\
\text { potential problems }\end{array}$ & 4.05 & 0.76 \\
\hline Improvement & $\begin{array}{c}\text { An active employee suggestion scheme is } \\
\text { used }\end{array}$ & 3.65 & 1.04 \\
\hline Improvement & $\begin{array}{l}\text { Improved customer services are } \\
\text { introduced to drive out failures }\end{array}$ & 4.15 & 0.81 \\
\hline Improvement & $\begin{array}{l}\text { The unit has quality culture of continuous } \\
\text { improvement }\end{array}$ & 3.95 & 0.95 \\
\hline Improvement & $\begin{array}{l}\text { The unit compares current quality } \\
\text { levels of services features with those of } \\
\text { competitors }\end{array}$ & 3.40 & 0.99 \\
\hline Improvement & $\begin{array}{l}\text { Uses information gained from customers } \\
\text { to improve services }\end{array}$ & 4.30 & 0.73 \\
\hline $\begin{array}{l}\text { Customer Focus } \\
\text { (internal) }\end{array}$ & $\begin{array}{l}\text { Unit provides what is needed by } \\
\text { employees for them to perform their jobs }\end{array}$ & 4.30 & 0.73 \\
\hline $\begin{array}{l}\text { Customer Focus } \\
\text { (internal) }\end{array}$ & $\begin{array}{l}\text { There exist methods to improve } \\
\text { coordination of interdependent tasks }\end{array}$ & 3.50 & 0.76 \\
\hline $\begin{array}{l}\text { Customer Focus } \\
\text { (internal) }\end{array}$ & $\begin{array}{c}\text { There are strong employee interactions } \\
\text { within organizational units }\end{array}$ & 3.35 & 0.59 \\
\hline
\end{tabular}


According to results, it can be concluded that the level of implementation of all analysed principles ranges from moderate to high (average grade ranging from 3,4 to 4,3), with the highest grades scored by the principles referring on employees and the assured resources $(4,30)$ as well as using information gained from customers to improve services $(4,30)$. Improvements can be done in strengthening the interactions among organizational units $(3,35)$ and comparing quality levels of services with those of competitors $(3,40)$ and fostering coordination of interdependent tasks $(3,50)$.

Cronbach's alpha coefficient as a measure of internal consistency reliability of scale was calculated for all three constructs - customer focus, continuous improvement and employee engagement. As can be seen from tables $2-5$, results demonstrated satisfactory level of reliability:

Table 2. Cronbach's alpha coefficient for all three constructs

\section{Reliability Statistics}

\begin{tabular}{|c|c|}
\hline Cronbach's Alpha & N of Items \\
\hline .935 & 19 \\
\hline \multicolumn{2}{|c|}{ Source: Authors } \\
\hline
\end{tabular}

Table 3. Cronbach's alpha coefficient for internal customer focus

Reliability Statistics

\begin{tabular}{|c|c|}
\hline Cronbach's Alpha & N of Items \\
\hline .789 & 3 \\
\hline \multicolumn{2}{|c|}{ Source: Authors } \\
\hline
\end{tabular}

Table 4. Cronbach's alpha coefficient for employee engagement

Reliability Statistics

\begin{tabular}{|c|c|}
\hline Cronbach's Alpha & N of Items \\
\hline .896 & 9 \\
\hline \multicolumn{2}{|c|}{ Source: Authors } \\
\hline
\end{tabular}

Table 5. Cronbach's alpha coefficient for continuous improvement

\section{Reliability Statistics}

\begin{tabular}{|c|c|}
\hline Cronbach's Alpha & Nof Items \\
\hline .921 & 7 \\
\hline
\end{tabular}

Source: Authors

Since Cronbach's alpha coefficients were satisfactory for all constructs, composite variables were calculated and used in correlation analysis to prove the hypotheses.

In order to test the normality of distribution (McDonald, 2014), and having in mind the sample size $(<50)$, the Shapiro-Wilk test was conducted. Based on the obtained results, Spearman correlation coefficient was calculated and presented in tables 6 and 7 . 
Table 6. Spearman's correlation coefficient between internal customer focus and continuous improvement

\begin{tabular}{|c|c|c|}
\hline & & Continuous improvement \\
\hline Internal customer focus & Correlation Coefficient & 0.318 \\
\hline
\end{tabular}

Note: ${ }^{* *}$ Correlation is significant at the 0.01 level (2-tailed)

Source: Authors

Table 7. Spearman's correlation coefficient between employee engagement and continuous improvement

\begin{tabular}{|c|c|c|}
\hline & & Continuous improvement \\
\hline Employee engagement & Correlation Coefficient & $0.840^{* *}$ \\
\hline
\end{tabular}

Note: ${ }^{* *}$ Correlation is significant at the 0.01 level (2-tailed)

Source: Authors

Correlation between two variables is quantified with a number which varies between -1 and +1 . Zero means there is no correlation and 1 indicates complete correlation, while values between 0 and 1 are interpreted in the following way (Schober, Boer and Schwarte, 2018:1765; Akoglu, 2018:92):

Table 8. Interpretation of correlation coefficient

\begin{tabular}{|c|c|}
\hline Correlation coefficient & Interpretation \\
\hline$r>0.70$ & Strong correlation \\
\hline $0.40 \leq r \leq 0.70$ & Moderate correlation \\
\hline $0 \leq r \leq 0.40$ & Weak correlation \\
\hline
\end{tabular}

Source: Authors

According to the interpretation criteria shown in table 8, it can be concluded that the obtained results presented in table 6 and table 7 demonstrate statistically significant strong correlation between constructs Employee engagement and Continuous improvement, while the correlation between Internal customer focus and Improvements has not been detected. Therefore, it can be concluded that hypotheses $\mathrm{H} 2$ has been confirmed, while $\mathrm{H} 1$ not. One of the reasons may arise from the fact that the level of implementation of some activities related to employee engagement are still higher than those related to internal customer focus. In order to verify relationship between those principles further and more detailed research is needed. 


\section{CONCLUSION AND DISCUSSION}

Research results from the Croatian public health sector have shown that quality managers are familiar with TQM principles and are taking action in relation to their implementation. Three TQM principles were chosen for the purpose of this research - employee engagement, continuous improvement and internal customer focus (employees). Descriptive statistics demonstrated that the stated principles achieved a medium to high score with regard to level of implementation (average grade ranges from 3.4 to 4.3). In addition to the average score pertaining to the extent of implementation, the relationship between employee engagement and continuous improvement as well as the relationship between improvement and internal customer focus (employees) were analysed (Spearman's correlation coefficient).

Results have shown that statistically significant strong positive relationship exists between some of the analysed constructs. Namely, employee engagement is significantly positively correlated with continuous improvement. The other correlation, the one between internal customer focus (employees) and continuous improvement has not been detected.

The scientific contribution of this study is that it expands knowledge on the role of quality principles for the public health services, with focus on employee engagement in the improvement process, as preconditions to creating a good working environment. The study's applicative contribution is that its results can serve as guidelines for quality managers to facilitate the effective implementation of quality management principles in public health institutes with the focus on internal customers (employees).

A limitation of this study is the sample size. Accordingly, in addition to Public Health Institutes, researches could be expanded on other public health institutions both in Croatia as well as in neighbouring countries. After conducting the research authors concluded that further and more detailed research is needed in order to further examine the relationship between internal customer focus (employees) and continuous improvement as TQM principles.

Furthermore, future research could focus on the measurement of patient satisfaction and the analysis of the connection between employee and patient satisfaction, as well as on the analysis of impacts of TQM principles on patients' and employees' satisfaction.

\section{REFERENCES}

Akola, H. (2018) "User's guide to correlation coefficients", Turkish journal of emergency medicine, 18 (3), pp. 91-93. https://doi.org/10.1016/j.tjem.2018.08.001

Arndt, M., Bigelow, B. (1995) “The implementation of TQM in hospitals: How good is the fit?" Health care Management Review, 20(5), str. 7-14

Arsis, M., et al. (2012) "The effect of TQM on employee loyalty in transition economy", Serbia. Total Quality Management and Business Excellence, 23(6), 719-729. doi: https://doi.org/10.1080/14783363.2012.669930

Brajer-Marczak, R. (2014) Employee engagement in continuous improvement of processes, Management, 18 (2), pp. 88103. https://doi.org/10.2478/manment-2014-0044. 
Brook, J. (2019) Why Employee Engagement Is Key To Company Success, https://www.socialchorus.com/blog/ employee-experience/employee-engagement-key-to-company-success/ accessed 20.10.2019.

Counte, M. A., Glandon, G. L., Oleske, D. M., Hill, J. P. (1995) "Improving hospital performance: Issues in assessing the impact of TQM impact activities". Hospital and Health Services Administration, 40(1), pp. 80-94.

Džakula, A., et al. (2014) "Croatia: Health system review". Health Systems in Transition, European Observatory on Health Systems and Policies, 16(3), pp. 1-162.

HRN EN ISO 9000, Quality management systems - Fundamentals and vocabulary (ISO 9000:2015; EN ISO 9000:2015), Croatian Standards Institute

HRN EN ISO 9001, Quality management systems - Requirements (ISO 9001:2015; EN ISO 9001:2015), Croatian Standards Institute

International Organization for Standardization (2015), Quality Management Principles, ISO Central Secretariat, Geneva, https://www.iso.org/files/live/sites/isoorg/files/archive/pdf/en/pub100080.pdf

Kahn, W. A (1990) "Psychological Conditions of Personal Engagement and Disengagement at Work", Academy of Management Journal. 33 (4), pp. 692-724.

Kanji, G. K. (2002) Measuring Business Excellence, London: Routledge-Taylor \& Francis Group.

Karia, N, Asaari, M. H. A. H. (2006) "The effects of total quality management practices on employees' work-related attitudes", The TQM Magazine, 18(1), pp. 30-43, https://doi.org/10.1108/09544780610637677

McDonald, J. H. (2014) Handbook of Biological Statistics, 3rd Edition, Sparky House Publishing, Baltimore, Maryland, USA.

Mosadeghrad, A. M. (2015). "Developing and validating a TQM management model for healthcare organisations". The TQM Journal, 27 (5), pp. 544-564., https://doi.org/10.1108/tqm-04-2013-0051

Oakland, J. S., Total Quality Management text with cases, Elsevier Butteworth - Heinemann, Oxford, Burlington

Paul, E. (2017) Employee On boarding, HR Onboarding Effective Ways to Improve Employee Engagement, https://www. emptrust.com/blog/employee-engagement-a-key-hr-strategy accessed 20. 10. 2019.

Pekar, J. P. (1995). Total quality management: guiding principles for application, Philadelphia: American Society for Testing \& Materials Petersen

Rizal, N. M., Wahl, Y. B. (2011) „Power comparisons of Shapiro-Wilk, Kolmogorov-Smirnov, Lilliefors and AndersonDarling tests", Journal of Statistical Modelling and Analytics, 2 (1), pp. 21-33.

Salaheldin, S. I., Mukhalati, B. A., (2009) "The implementation of TQM in the Qatari Healthcare sector", Journal of Accounting - Business \& Management, 16 (2), pp 1-14

Schalk, R., van Dijk, W. (2005), "Quality management and employee commitment: Illustrated with examples from Dutch health care", International Journal of Health Care Quality Assurance, 18 (1), pp. 32-40. https://doi. org/10.1108/09526860510576956

Schobert, P., Boer, C., Schwerte, L. A. (2018) “Correlation Coefficients: Appropriate Use and Interpretation”, Anaesthesia and analgesia, 126(5), pp. 1763-1768.

Short, P. J., Rahim, M. A. (1995). “Total quality management in hospitals", Total Quality Management, 6, pp. 255-263. doi: https://doi.org/10.1080/09544129550035422

Sokovic, M., Pavletic, D., Kern Pipan, K. (2010). „Quality Improvement Methodologies - PDCA Cycle, RADAR Matrix, DMAIC and DFSS", Journal of Achievements in Materials and Manufacturing engineering, 43(1), pp. 476-483.

Tari, J. J., Sabater V. (2006). "Human aspects in a quality management context and their effects on performance". The International Journal of HR Management, 17(3), pp. 484-503, https://doi.org/10.1080/09585190500521557

Werner, T., Weckenmann, A. (2012), "Sustainable quality assurance by assuring competence of employees", Measurement, 45 (6), pp. 1534-1539, ISSN 0263-2241, https://doi.org/10.1016/j.measurement.2012.02.025. 
A. M. Vrtodušić Hrgović, K. Črnjar, I. Škarica: Employee Engagement and Improvement as Important... Zbornik Veleučilišta u Rijeci, Vol. 8 (2020), No. 1, pp. 189-201

Varey, J. R. (1995). Internal marketing: a review and some interdisciplinary research challenges. International Journal of Service Industry Management, 6(1), pp. 40-63.

Zabada, C., Rivers, P. A., Munchus, G. (1998). "Obstacles to the application of total quality management in health-care organizations". Total Quality Management, 9(1), 57-66. https://doi.org/10.1080/0954412989261

Yang, C. C. (2003). "The establishment of a TQM system for the health care industry". The TQM Magazine, 15(2), pp. 9398. https://doi.org/10.1108/09544780310461107

Yung, W. K. C. (1997) "The values of TQM in the revised ISO 9000 quality system", International Journal of Operations \& Production Management, 17(2), pp. 221-230. https://doi.org/10.1108/01443579710158078 
(c) $(1) \circledast$

Creative Commons Attribution -

NonCommercial 4.0 International License
Izvorni znanstveni rad

https://doi.org/10.31784/zvr.8.1.18

Datum primitka rada: 30. 12. 2019.

Datum prihvaćanja rada: 2. 3. 2020.

\title{
UKLJUČENOST ZAPOSLENIKA I POBOLJŠANJA - ZNAČAJNA NAČELA TQM-A U ZAVODIMA ZA JAVNO ZDRAVSTVO
}

\author{
Ana-Marija Vrtodušić Hrgović
}

Dr. sc., izvanredna profesorica, Sveučilište u Rijeci, Fakultet za menadžment u turizmu i ugostiteljstvu, Primorska 42, p. p. 97, 51410 Opatija, Hrvatska; e-mail: anamariv@fthm.hr

\section{Kristina Črnjar}

Dr. sc., izvanredna profesorica, Sveučilište u Rijeci, Fakultet za menadžment u turizmu i ugostiteljstvu, Primorska 42, p. p. 97, 51410 Opatija, Hrvatska; e-mail: kcrnjar@fthm.hr

\section{Ivana Škarica}

Mag. oec., doktorandica, Sveučilište u Rijeci, Fakultet za menadžment u turizmu i ugostiteljstvu, Primorska 42, p. p. 97, 51410 Opatija, Hrvatska; e-mail: ivanaskarica969@gmail.com

\section{SAŽETAK}

Osiguranje kvalitete u javnom zdravstvu predstavlja jedan od ključnih čimbenika kvalitete zdravstvene usluge. Sukladno tome raste svijest o nužnosti integriranja sustava kvalitete i njihovih načela u zdravstveni sustav. Njihova je uloga važna u kontekstu osiguranja kvalitete u skladu sa zahtjevima pacijenata kao i u procesu poboljšanja kvalitete zdravstvene usluge. Ključni su za uspješnu provedbu sustava upravljanja kvalitetom i odnose se na: usmjerenost na kupca, vodstvo, uključenost ljudi, procesni pristup, poboljšavanje, donošenje odluka na temelju činjenica i upravljanje odnosima, $U$ ovom se radu daje prikaz rezultata istraživanja o razini primjene načela TQM-a u Zavodima za javno zdravstvo u Republici Hrvatskoj a vezano uz uključenost zaposlenika, poboljšanja ifokus na internog kupca. Analiza je usmjerena na uturđivanje veze između uključivanja zaposlenika i poboljšanja te fokusa na unutarnjeg kupca (zaposlenika) i poboljšanja. Rezultati pokazuju da postoji snažna povezanost između uključenosti ljudi i poboljšanja, dok između primjene poboljšanja i usmjerenosti na unutarnjeg kupca nije uturđena povezanost. U kontekstu standardizacije kvalitete usluga u javnom zdravstvu rad ima za cilj proširiti teorijske spoznaje o TQM načelima i to posebno za uključenost zaposlenika, fokus na internog kupca (zaposlenika) i poboljšanja procesa. Dobiveni rezultati mogu poslužiti kao osnova za poboljšanje postojeće prakse implementacije TQM-a u javno zdravstvenom sustavu s posebnim naglaskom na ulogu zaposlenika u tom procesu.

Ključne riječi: upravljanje potpunom kvalitetom, uključivanje zaposlenika, usmjerenost na internog kupca, Zavodi za javno zdravstvo 